\title{
Muslim Healers and Healing: An Ethnographic Study of Aboabo Community of Ghana
}

\author{
Samuel Adu-Gyamfi ${ }^{*}$ Abubakar Teikillah, Ali Yakubu Nyaaba, \\ Mariama Marciana Kuusaana, Benjamin Dompreh Darkwa, Lucky Tomdi \\ Department of History and Political Studies, Kwame Nkrumah University of Science and Technology, Kumasi-Ghana \\ Corresponding author: E. mail: mcgyamfi@yahoo.com
}

(Received 23 May 2020; Accepted 7 August 2020; Published 20 November 2020)

\begin{abstract}
Societies that have accepted Islam have blended their native culture with what was, rightly and wrongly, linked to Islam. Here, we present an example of this combination concerning traditional healing processes in Muslim societies. Focusing on the Aboabo community, we did an ethnographic study of healing processes and rites used by healers and further discussed the rites, practices, contributions and challenges of Muslim traditional healing in the community. Based on a qualitative research approach, the current study uses both theories of diffusionism and syncretism and empirical evidence to highlight the mode of treating some diseases using medicinal plants and rituals including prayers and Qur'an verses recommended in ancient narrations received from earlier Muslim societies (particularly Arab societies). Although Muslim traditional healers are nearly disappearing from many contemporary Muslim societies, the continuation of their presence in some societies such as Aboabo is partly related to the standard of living of the people. The know-how of these healers is mainly limited to their native traditions, some principles of Islam and related questionable narrations. The activities of Muslim traditional practice have remained archaic, often questionable and/or unhygienic despite Islam's exhortation of its believers to respect, among other things, cleanliness and hygiene, and especially to increasingly develop their knowledge in major areas such as those concerning medicine and anthropology. Finally, we realized that although the idea of modernization of Muslim traditional healing in Ghana is expressed in some local discourses, it remains at the periphery.
\end{abstract}

Keyword: Muslim, Islam, Aboabo community, Healing, Muslim healers, Traditional Medicine, Cultures 


\section{Introduction}

Since pre-historic times in Ghana, and Africa in general, discourses on ill-health have always been approached via a multi-factor framework which incorporates both biological and spiritual burdens (Sackey 2002). To that end, disease burdens have always been associated with both environmental factors and malevolent spirits across the continent (Twumasi 1975). Similarly, the definition, cure and treatment of diseases in Africa have over the years been a core part of the religious orientation of the healer and the patient. It has further been suggested that in countries with scarce medical resources, and changing cultural orientations like Ghana, the approach to health and well-being is based on the stakeholder's understanding on health (Tabi et al. 2006). Therefore, aside the reliance on medicinal plants, Ghanaians and Africans for that matter, have also relied on faith healing which emanates from religious orientations and beliefs, to seek solutions to several existential problems of which the discourses of health cannot be dissociated (Adu-Gyamfi 2016).

In Ghana, it has been reported that about $63 \%$ of the citizens are Christians with $16 \%$ and 21\% representing Muslims and Traditionalists respectively (Tabi et al. 2006). Historically, the earliest forms of religion are believed to have evolved out of people's search for security, and especially, a causal explanation of misfortune, ill-health and how to cure same (Yusif 2014). Significantly, religion and healing are reported to be intertwined. While the former addresses the spiritual and psychosocial needs of man, medicine and healing, in turn, seek the solution to man's physical and psychological needs (Adu-Gyamfi 2014; Sackey 2002).

Although the Holly Qur'an (sacred text of Islam) is a religious text par excellence, it includes innumerable scientific signs related to the major fields of knowledge (Chaabani 2019). Some of these signs concern our health such as hygienic advice or the cure with natural products. Moreover, in many Qur'an verses, Allah encourages all peoples to seek knowledge and look for the mysteries of His universe and creatures including humankind and therefore to develop, among other fields of knowledge, what we currently call anthropology and medicine (Chaabani 2011). In addition to what has been reported in the Qur'an, Muslims should follow the appropriate meaning of sayings of the Prophet Muhammad (Sala Allaho Alaihi ouia 
Sallim) called "Ahadith" (plural of "Hadith"), but the latter must be 'Sahih' (very likely, really said by the prophet) and above all in complete agreement with the Qur'an. As we will note below, some of these Ahadith give directions to some health advice similar to those given in Qur'an. Aside these two unique sources of Islam, innumerable books on Islam have been published but, unfortunately, they often include considerations falsely linked to Islam (such as questionable interpretations of the Qur'an verses, contradictory narrations, some pre-Islamic beliefs, fibs and warp). Accumulating during the past fourteen centuries, these considerations have more or less permeated world Muslim societies (Chaabani 2019). In one of these societies, Aboabo community in particular, we explore the healing processes of Muslim traditional healers. This exploration, among other things, serves as a model to show how, what is rightly and wrongly linked to Islam has been blended with the native culture of a society which has embraced Islam.

The knowledge of healing, according to some Muslim traditional healers, is divided into two, Swahir and Batin (physical and hidden) (Carter 2018). The treatment for Swahir (physical) sickness is regarded as the application of herbs to the affected part of the body or based on the prescription of the Quran or Hadith. On the other hand, the Batin (hidden) aspect of health and healing include dissociating people from magic, sorcery, witchcraft, the attachment of jinns, madness and other spiritual forces that are regarded as evil in Islam (Carter 2018). Among Muslim healers, diseases that are regarded as Batinare are mostly cured by recitations (Rukya) of some recommended chapters or verses of the Holy Quran. Surats Fatiha, Ikhlass, Al falaq, Al Jinni, Kafirun, Alqadr and verses such as Quran (3: 173) which reads "Hasbunallah Wanimal Wakil" and Ayatul Qursiyu (it is the verse 255 of Surat, the cow, Albaqara), are relevant in curing Batin ${ }^{1}$.

Indigenous Muslim healing traditions, referring to the meaning of some Qur'an verses, recommend the use of natural products to cure diseases (Ali et al. 2018). Notable among these include the use of honey, black seed, olive oil, and Zamzam water (water from the Well of Zamzam located within the Masjid al-Haram in Mecca, Saudi Arabia) among many others for healing purposes (Ali et al. 2018). In the case of honey, the Quran says: "there comes forth from their bellies, a drink of varying colors wherein is healing for men" (Surat An-Nahl: 16: 69). Honey has been mentioned repeatedly by the Prophet as a "healing" and 'blessing", as well as the best medicine. It was reported

\footnotetext{
${ }^{1}$ Batin is considered by Muslim traditional healers as the kind of disease that is hidden.
} 
that the Prophet told his followers that: "There are two cures for you: honey and the Qur'an; honey as medicine for the body and the Qur'an as a medicine for the soul. Benefit from the use of the Qur'an and honey." and "Honey sharpens the sight and strengthens the heart." In modern parameters of medicine, it has been discovered that the pharmacopoeia content of honey has antibacterial properties as well as other health benefits. It is composed of water, simple and complex sugars, minerals, enzymes and amino acids among different vitamins known to promote good health (White 1979).

As already reported in the literature, indigenous Muslim healers combine the philosophies of the religion with the local cultural practices to proffer solutions to the health needs of their clients (Edwards 2011). In their healing processes, Muslim healers use some verses which may be written, washed and drunk, and sometimes to clean the body (Owusu-Ansah 1983). Some of the verses are also molded into the form of amulets or talismans (Tabatabai 1984). Historically, these verses have been used by many Asante notables including Kings who sought to protect themselves against calamities by purchasing and wearing the amulets containing Quran verses in different forms (Owusu-Ansah 1983).

The current contribution focuses on Muslim healers and healing in Aboabo, a community located in the Asawasi constituency in Kumase, the capital of the Asante Region of Ghana (Akyeampong 2006). It is located about two kilometers (2km) west of the Kumase Central Market (Mensah 2010). The town is believed to be the largest Zongo community in the Asante Region of Ghana (Akyeampong 2006; Mensah 2010). Historically, it is believed that the place, currently referred to as Aboabo was not conducive for human habitation as the area composed of many rocks (Mensah 2010). Etymologically, Aboabo was coined from an Akan term "aboo-aboo," literary translated as either "stones-stones" or "rocks-rocks" (Mensah 2010). However, in an interview with a respondent, he opined that: "the etymology of Aboabo is linked with a local river called 'Abo aba' -which is currently referred to as Palale in the community" (Interview, Atapasa, 2018). Due to the availability of job opportunities in Kumase, it has been reported that people from the Northern part of Ghana who were mostly Muslims, started occupying the area around the $19^{\text {th }}$ century (Mensah 2010). Till date, majority of the population in Aboabo adhere to Islamic practices and dictates. From inception, Muslim healing traditions have formed a core part of the community.

Essentially, the community has seen the proliferation of different practitioners undertaking myriad of healthcare practices to ensure the delivery of proper healthcare 
for the people. The popularity of the community's Muslim healing practices notwithstanding, little attention has been paid to this area of study.

Significantly, we have come across many studies with particular attention to religious healing and Muslim traditional healing in particular, across time and varied epochs. Although, most of the studies have addressed how Islam has been syncretized within indigenous cultures, relevant attention has not been paid to how the indigenized religion shapes the nature of Muslim healing among the Aboabo populace in the Asante Region of Ghana. Through an ethnographic and historical study, we aimed among other things, to ask questions and answer same concerning the rites and practices, contributions and challenges of Muslim healing in the Aboabo community. Under the discussions, we use both empirical evidence and the theories of diffusionism and syncretism to study the mode of treating certain ailments with both medications and an amalgam of legitimate prayers and verses by Muslim healers within the sphere under review.

\section{Method of Study}

We employed a qualitative method of research grounded in both primary and secondary sources. Primarily, we sourced information using semi-structured oral interviews. In all, we interviewed thirty (30) participants -twenty clients and ten (10) indigenous Muslim healers. Based on the stratified sampling technique, we selected and interviewed ten indigenous Muslim practitioners at their various healing centers within the community. The criteria for selection and inclusion were based on the longevity of their service coupled with the perceived efficacy of healing practices based on preliminary testimonies from their clients. This notwithstanding, we considered the level of memorization of the Quran for exorcism and healers who have received informal and/or traditional education from known earlier healers or Imams within or outside of the Aboabo community. Among the twenty (20) clients, the authors used a simple random sampling to select the participants for interview in both their abodes and work places. We included fourteen (14) females and six (6) males. Significantly, out of the twenty (20), we purposively selected five (5) clients who belong to different religious persuasions. Before the interview, we sought for consent from both practitioners and the clients. Interviews were conducted in Asante Twi, Hausa and English. The results were further transcribed and analyzed thematically. Also, we fell partially on the theories of 
diffusionism and syncretism to enrich and expand our earlier understanding of the discourse on Muslim healing. We analyzed the findings from the field with information from the primary and secondary sources and the already stated theories.

We also observed the healing sessions of the Muslim traditional healers at their healing centers. We further asked the practitioners questions about some of their practices for clarification. During the field work, emphasis was placed on the norms, forms, or styles as well as traditional methods or ways employed by the indigenous Muslim medical practitioners. We spent one week observing and making notes on the activities of the Muslim traditional healers at the Shehu Makin Herbal and Spiritual Center. Similarly, we spent five days at Ibrahim Na Lado Healing Center observing the practices of the healers. Same approach was used at the other healing centers we visited to gather relevant data for this research. Significantly, information from books and journal articles as well as internet sources were gleaned to corroborate the primary data.

On the field, we noticed clients' inability to speak or disclose valuable information in their zeal to protect the secrecy of their healers. In piecing this manuscript, access to relevant books on the subject was very cumbersome. Also, most of the literature (s) for the study was written in Arabic and hence the issue of translation was problematic and time consuming. These challenges notwithstanding, the findings are well corroborated to make useful generalizations for both academia and policy making.

\section{Theoretical Underpinnings}

The current study finds the theories of diffusionism and syncretism useful to our contribution to the debate on Muslim medicine and healing practices. Under this section, we briefly discuss the two theories and reflect on how both have been adopted within the current discourse. We begin with diffusionism and then, syncretism.

Diffusionism involves an attempt to develop an understanding for the nature of cultural origins and traits (Hein 2014). It emphasizes the trans-cultural transmission of ideas (Barnard 2000). Its utmost presupposition is that humankind is uninventive: things are invented just once and transmitted across boundaries and among people over time (Barnard 2000; Diah et al. 2014). Diffutionists are of the view that ideas can be transmitted directly or through a complex network of migration (Diah et al. 2014). Proponents of this theory support the idea that there are several cultural centers from where communities borrow their ideas (Diah et al. 2014; Hein 2014; Barnard 2000). 
Applied to the Aboabo community, it can thus be argued that the healers and the community members have diffused Arabian cultures and Islamic concepts into their social and cultural constructs. With its emphasis on people as uninventive, diffusionists have been challenged on the basis that they tend to be ethnocentric treating the cultures of developing countries as inferior to the Western world.

We now turn to syncretism. The theory of syncretism has received different views by authors as they have not yet reached a consensus concerning an acceptable definition of the concept. Syncretism, also referred to as religious mixture, emphasizes the blend of cultures and ideas spanning different spaces (Colpe 1977; Stewart 1999; Droogers 1989). It seems to suggest that, as culture and ideas move beyond boundaries and contacts among different believers' increases, religious syncretism would be inevitable. Societies have over the years tried to adopt alien religions to their indigenous ones sometimes merging their social and political aspects of their traditions (Droogers 1989). Proponents of this theory are of the view that faith, cultures and customs are mostly combined within every community (Colpe 1977). Applied to the study area under review, indigenous cultural beliefs and practices have been tied to Islamic religion with each Muslim shaping the religion within his/her belief systems and practices. In other words, Islam has been indigenized within the Aboabo community with Muslim healers discharging their duties from an admixture of the dictates of both Islamic religion and native cultural norms (Stewart 1999). While these healers have tried to shape the religion to their advantage, authors are of the view that the admixture or blending of religions and cultural norms violate indigenous belief systems (Droogers 1989).

Within the current discourse, we apply the theories to how healing practices and major principles of Islam and related questionable narrations have been transmitted to the Aboabo community and blended with the native cultural, social and healing practices of the people and the healers in particular.

\section{Findings and Discussions}

Practices and norms used by some Muslim healers at Aboabo

It has been reported that various practices influence the health and well-being of all adherents of the traditions of Muslim societies (Farooqi 2006). Through time, healing practices in general, and Muslim healers in particular, have gone through several transformations (Adu-Gyamfi 2014). While maintaining their old traditions on healing, 
the Aboabo community has adopted and syncretized various alien healing cultures into the community. Most of the alien cultures that have been blended have deeply affected the traditional systems of the community. This notwithstanding, several practices have also withstood the test of time. In this study, we witnessed the healing processes within the community. Within the health centers visited, the complaints were diarrhea, stomach aches, headache, chest pains, and poor eyesight. Other complaints which involved spiritual and psychological attention include epilepsy (Farfaduwa), ailment caused by jinns and early stage of hunchback (Kankaranfu). Among other things, the most serious complications treated within the community include epilepsy (Farfaduwa), early stage of hunchback (Kankranfu) and ailments caused by jinns. Under this section, we observed the activities in the consulting rooms of the Muslim healers. This has enabled us to discuss the practices and strategies used by Muslim healers within the Aboabo community to meet the health needs and challenges of the people.

\section{Rites associated with the treatment of early stage of hunchback (Kankaranfu)}

An interviewee hinted that the common symptoms of the early stage of hunchback (Kankaranfu), includes, fast breathing, chest pain and general body pains (Interview with Makin 2018). The cure for such sickness is very practical with reading of some verses of the Holy Quran. Depending on the stage of the sickness, the precise verses recited are, Ayaatul Qursiyu (it is the verse 255 of Surat, the Cow, Albaqara), and Surats Yasin, El-Falaq and Alnnas (Interview with Makin 2018). From our observation and earlier research on the subject (Adu-Gyamfi 2014; Owusu-Ansah 1983; Seebaway 2011), it appeared that this form of healing normally takes place and is effective at dawn, especially, within the hours of 3:00 am to 6:00 am. The practice was very crude. A healer; Makin hinted that:

\footnotetext{
The healing rituals performed for a person afflicted with Kankranfu takes place at dawn. Before the practice, the patient would be asked to go naked; I do not allow any man to witness the nakedness. In adherence to my imposed principles and that of this community, it is my duty as a healer to protect the person under my care. In that regard, I forbid all persons, including some of my employees within this place to see my clients' nakedness (Interview Makin, Aboabo, 2018).
}

We infer that the doctrines proposed by Muslim Imams and native doctrines that forbid men to see ones nakedness has been adopted by native Muslim healers. As adherents of the Islamic faith, it is appropriate for the healer to forbid third parties from observing 
the process. It can also be stated that due to the nakedness of clients as requirements within the healing rites, practitioners find it most appropriate to conduct the healing session at dawn to forbid others from witnessing the practice. Although we were not allowed to witness the process, we could hear the sound and screaming of the patients during the process. Markin affirms that his practices regarding the treatment of the early stage of hunchback (kankaranfu) is able to cure the early stage of the disease. He also affirmed that he obtained his traditional medical knowledge from his grandfather by accompanying him to villages and other suburbs of Asante. Aside learning the art, it is instructive to also state that as existing studies on early stage of hunchback (kankaranfu) show similar approaches in its treatment, the healers within the Aboabo community might have adopted the practices associated with the treatment of the ailment in question from a different culture. This enhances our understanding and idea of human beings as uninventive and borrowers of ideas from alien cultures (Diah et al. 2014).

Another aspect of the healing processes of Kankaranfu is the use and application of indigenous herbs. Makin further hinted that:

The process does not end with the dawn practice alone. I also use natural herbs and washed writings from Allo (washing slate) to treat my clients. I inscribe Quran verses with the help of my Taddawa (ink) and Alkalami (pen) on Allo (slate). Specifically, I wash the words for the patient to drink or bathe with it to heal him from his sickness (Interview Makin, Aboabo, 2018).

The above signifies that, although there is cornucopia of rituals involved in the processes for the treatment of hunchback (Kankaranfu), herbs were often used. From our interview with Makin, after applying natural herbs, he uses ink (Taddawa) ${ }^{2}$, and pen (Alkalami $^{3}$ to inscribe some Quran verses which are believed to be efficacious on washing slate $(A l l o)^{4}$ (see Fig. 1). The result is later washed to be given to the patient to drink and, sometimes, to bath with it. According to Adu-Gyamfi (2014), once drank, every evil spirit part ways with the patient. Where a patient's case is spiritually severe, a talisman and amulet is given to the patient. Here, we see a syncretic approach applied among the stakeholders in the community by blending outside culture with indigenous ones. Aside the continuous consumption of indigenous herbs, the community has also adopted the use of amulets which is a common practice of Muslim societies. The

\footnotetext{
${ }^{2}$ Taddawa (Ink made up of sugar or a tree, the sugar is allowed to burn for some time and water is added to it to form the ink)

${ }^{3}$ Alkalami (Pen made up of either a stick or palm branch)

${ }^{4}$ Allo (A special slate that is used by Muslim healers to write Quranic verses and wash it for patient to drink)
} 
literature has discussed the roles and efficacy of amulet and talisman made with Quran verses in Muslim native medicine. Among other things, the talisman and amulets serve as protective mechanism against different forms of evil (Owusu-Ansah 1983). The approaches enumerated above are consistent with the approach discussed by OwusuAnsah and Seebaway but what makes Makin's approach very unique is his ability to heal hunchback (Kankaranfu).

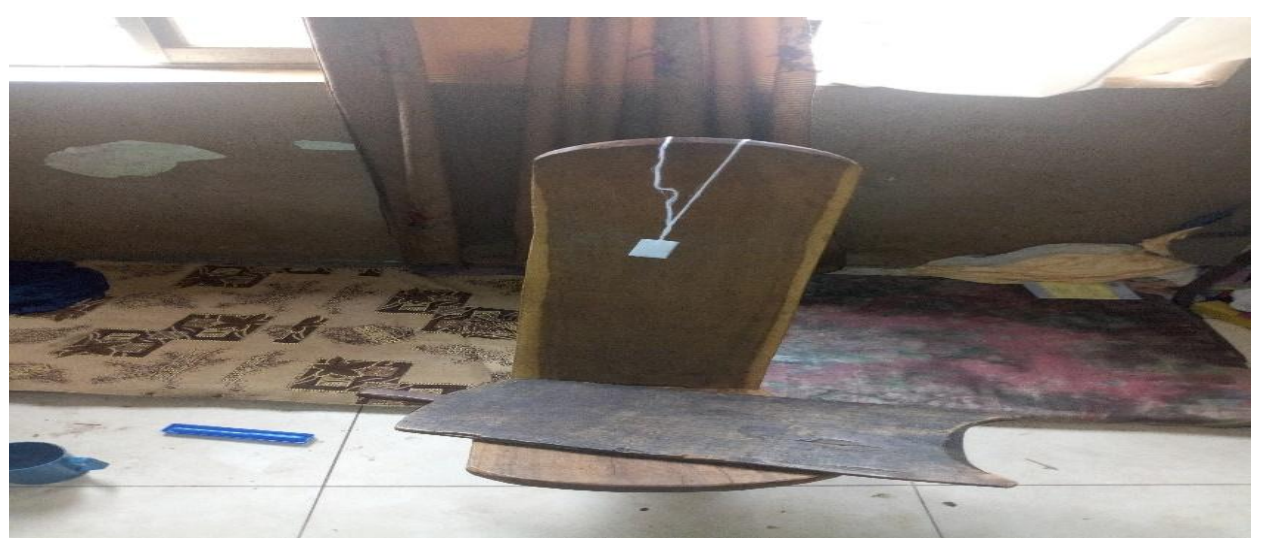

Fig. 1 Image, taken from Muslim healing centers, shows a slate on which the healers write and wash the result for drinking and purification purposes

\section{Rites associated with Jinns}

According to the writings of Muslims, jinns are invisible beings created by Allah from smokeless fire (See Quran: 72 Surat Al Jinn). Some authors agree that jinns form a separate world other than human world (Khalifa and Hardie 2005). Like human beings, jinns can marry, reproduce, eat, drink and die (Khalifa and Hardie 2005). Khalifa and Hardie (2005) stress that "they have the power to take on different shapes and are capable of moving heavy objects almost instantly from one place to another" (Khalifa and Hardie 2005). Authors support the idea that jinns take different forms; good and evil, with the evil ones associated with numerous calamities afflicting the world (Kpobi and Swartz 2018). To that extent, people with Islamic religious orientation believe that jinns have the ability to cause both physical and mental harm to the wellbeing of humans (Khalifa and Hardie 2005). Life events, spiritual possessions and certain psychotic symptoms may be associated with the activities of jinns. The idea of jinns has been diffused through various spaces to the current study area. In our engagement with Makin, he hinted that women are the main carriers of jinns. According to him; 
...women who do not cover their hair; those who do not cover their body properly; those who bath during mid night; those who walk in a deep bush or forest in the afternoon are the major carriers of jinns. Especially, to emphasize, those women who do not cover themselves very well become host of jinns (Interview Makin, Aboabo, 2018).

In a similar manner, jinns are believed to "inhabit caves, deserted places, graveyards and darkness" (Khalifa and Hardie 2005). According to Makin, there are two categories of jinns, namely; non-Muslim jinns (kufar) and Muslim jinns. This notwithstanding, the literature on Jinns argues that in Islam, jinns have been classified into various groups. According to Lim and his peers, Jinns can be classified into two; religious and pagans; males and females; and based on geographic locations (Lim et al. 2015). Information on jinns also highlights their ability to possess people with witchcraft and black magic which are used to perform evil deeds (Kpobi and Swartz 2018). Our informant; Makin, hinted:

Some jinns can plead with practitioners to spare them for rewards. It is equally worthy to note that while some jinns are very malevolent, others are very generous. With the most obstinate ones -like the Kufar-I have to cane them before they come out from their hosts. Mostly, I question the jinns concerning how long they have been with the host and how many they are inside the host; some people might possess as many as seven jinns (Interview Makin, Aboabo, 2018).

Depending on the one the patient is hosting, the level of impact differs on a personal level. When a Muslim woman is affected by the non-Muslim (kufar) jinn, healers normally find it challenging to dissociate it through exorcism from the host. Within the healing processes in such instances, healers sometimes make sacrifices to appease or compensate the jinn. The materials needed for such sacrifices include white live sheep, white and red kola nut, millet, guinea fowl, chicken, masa ${ }^{5}$ and nono (milk). The above named materials which are requested by the healer are given to either a mother of twins or a blind man.

Like other religious orientations, exorcism is the special treatment for dissociating jinns, (believed to be evil spirit) from a person (Adu-Gyamfi 2016). In Islam, exorcism is referred to as Rukya ${ }^{6}$. Rukuya as a healing practice has been studied through history with the practice dating back to the era of Prophet Mohammed. It

\footnotetext{
${ }^{5}$ Masa (A common food in the Zongo communities, which is prepared with grinded maize and fried with oil).

${ }^{6}$ Rukya ( Muslim way of exorcism which involves recitation of some selected verses)
} 
involves the reading of recommended Quran verses for healing. Ayaatul Qursiyu, Wattabahu Maa Tatlu Shayatiin (it is the verse 102 of Surat, the Cow, Albaqara), and Surats El-Falaq and Ilnnass, are some of the recommended Quran verses used to exorcize a patient possessed by jinns (Interview with Makin 2018). When it finally comes out, a concoction is prepared for the victim. Like the treatment of hunchback (Kankaranfu), a concoction is made from the slate washing procedure to be administered to the patient by drinking. According to Adu-Gyamfi (2014):

The reason for the concoction or decoction is that the jinn left the victim's body as a result of the powerful words coming from the reading of the Qur'an so when the victim leaves for his or her place of residence the jinn could probably come back since the Qur'an would not be recited at that particular moment.

In contrast to the above, our interviewer, Makin, hinted that:

...The potion is given to protect the client...Since the potion given is derived from Quranic verses; it is meant to fill the client spiritually, preventing him or her from being possessed by other jinns. This notwithstanding, jinns can reappear or repossess the victim when the client does not heed to the instructions given; especially covering herself very well (Interview Makin, Aboabo 2018).

After the potion has been administered, the healer then prescribes a list of rules or ethics, which are to be observed by the clients. Significantly, exorcized clients who have recovered are advised against consuming certain foods like goat meat, duck meat and foods prepared outside their respective homes. In the rituals associated with the dissociation of jinns, it is evident that healing practices have been indigenized to fit the culture of the Aboabo people. In the discourse, we see a blend of cultures: indigenous and alien ones. Aside from some of the practices that are deemed indigenous, some elements of Muslim healing across space and time; such as reading of the Quran and washing of the slate, combine with the native medical practices of the Aboabo community signaling a cross-cultural transfer of ideas.

\section{Clients' Testimonies in Aboabo}

We interviewed clients who testified about the efficacy of the medical practices in the area under study. Under this section, we have relied on the testimonies of selected clients to develop narratives concerning the efficacy of the healing practices of noticeable healers in the community. Abass $\mathrm{Halima}^{7}$ is a thirty year old single woman,

\footnotetext{
${ }^{7}$ Interview with Abass Halima, work place. 30 January 2018
} 
who is a client of Shehu Makin. According to Halima, she heard about the success of Shehu Makin who is able to treat people with all forms of sicknesses. Prior to her visit to Makin; she hinted:

I had been told by a Muslim soothsayer that men are not proposing to me because of the activities of jinn. I became convinced about his claim because I had actually been having dreams. In these dreams, I see myself having intercourse with a particular man whose face I cannot see. According to the healer, I had been married to such jinn; making all men lose interest in approaching me. The healer stated emphatically, that any man who tries to approach me would taste the malevolence of the jinn. This statement drew my attention to a past event in my life: a young man who worked at the Ghana Commercial Bank proposed marriage to me sometime; suddenly, I was informed he had had a car accident and was admitted at the Manhyia hospital which eventually led to his death (Halima, Aboabo 2018).

Upon her visit to Shehu Makin, the latter identified the source of the jinn that attacked her as one inherited from her grandmother. According to her, Makin told her that when she was fourteen (14) years old, her grandmother woke her during the midnight to take her bath, which was very unusual. When she woke up, the next morning, her pant and underwear were wet. She informed her late grandmother and she affirmed that, "a spirit had possessed and married her". At the healing center, Makin assured her that the jinn would be exorcised. Beginning with the process, the woman reported that, Makin read some verses of holy Quran and gave her washed Rubutu written on allo. He poured the remaining rubutu into a 1.5 litre plastic container and asked her to use it for seven days. Two weeks later the jinn disappeared from her dreams and she had no sexual intercourse in her dreams anymore. She further hinted: "Makin assured me that a man will propose marriage to me and that things will work out very well for me".

The argument above clearly depicts that jinns can be classified on the bases of gender as indicated by earlier studies (Lim et al. 2015). The woman's argument of being possessed by jinns as a result of taking her bath at midnight is consistent with Khalifa and Hardie's earlier research in 2005 which argues that jinns can possess people in darkness.

More so, we infer from the above that as Africans and Ghanaians in particular, the indigenous cultural constructs of the Aboabo community still heavily rely on metaphysical tendencies to define and treat diseases. This notwithstanding, they do not 
necessarily conclude that all diseases encountered within the community are regarded as metaphysical; knowledge of disease as a social construction in the community, and Africa in general, has always existed with the notion of diseases as biological dysfunction of the human body (Adu-Gyamfi and Adjei 2017).

A similar study has been undertaken by Adu-Gyamfi in 2014 among an Islamic community in Sampa. In this study, the author discussed how bone-setting and the possession of jinns are indigenized and treated by native Muslim medicine within the community under review. In this current study, we add to the corpus of literature on Muslim medicine by discussing the treatment of mental health and Kankranfu within the praxis of Muslim medicine in the Aboabo community.

Aside from dissociating or exorcising jinns from people, as well as treating Kankaranfu and other complicated diseases, healers in the Aboabo community also provided cure for other diseases that are believed to be endemic in the Aboabo community. From a forty-year old literate client, Nkansah, we were informed:

I am a literate and renowned successful business man. I had visited Anwiam hospital in Dagomba line on several occasions with chest and bodily pains and was on admission several times, but to no avail. I heard a testimony from some clients of Aliu Atapasa and decided to "give-it-a-try". Since the day I reported my problem to the healer, he prepared some herbal medication and added prayers to it. In about two weeks from my visit, I started recovering. This has made me develop some level of trust for him, making me visit Aliu Atapasa anytime I feel unwell. Never mind the source of the disease, whether it is caused by physical or metaphysical forces, Aliu Atapasa is always willing to address the problems of his clients (Interview Nkansah, Aboabo 2018).

Concerning the treatment of mental health, we used a testimonial provided by one of the researchers as he observed the healing processes of one patient. Significantly, we have duly anonymized the name of the client. The client was a 25 year old woman who had a mental health complication and was conveyed by a taxi to Shehu Makin's shrine at Aboabo Number two (2). The healer upon seeing the victim declared that the victim had been possessed by a malevolent male jinn. Firstly, the healer performed ablution and placed his hands on the victim's head and began reading some Islamic Quran verses coupled with strange expressions and enchantments. The jinn started speaking through the victim with a masculine voice; it [the jinn] asked the healer to stop disturbing him, claiming that he is madly in love with the woman and would never leave her. The healer pleaded with him but his effort remained futile. For about three 
hours, Makin eventually exorcised the jinn after lashing the victim/client including the use of Rukya. Consequently, the researcher saw the patient had recovered when she asked in amusement; "how did I get here?" In a follow-up visit to the victim to ascertain the efficacy of the practice, the woman affirmed that: "I have not been challenged again; I will usually be visiting Makin for all my health related problems".

At Ahmed Inusah'shealing center, Aboagye ${ }^{8}$, a twenty nine year old university graduate had a mental health problem and was accompanied by his father to Ahmed Inusah. Interestingly, Aboagye's father is a bishop of a renowned Church in Aboabo Number One (1). Concerning Aboagye, he was chained by strong men due to his violent behaviour that was causing threat to everybody in the vicinity. The healer after receiving the client read some Quran verses and blew some air over Aboagye who suddenly gained his composure. After some hours, he was eventually healed and promised to visit him anytime he has a problem. Aboagye was sent back home without chains. In a subsequent visit to him, he confirmed that he continues with the prescribed Rukya and Rubutu at home.

The testimonies above suggest that people of different faith or orientation seek the services or support of Muslim healers due to individual's perceived efficacy and other related factors. Although believed to have some biological notions, mental illness as referred to in the praxis of traditional healing is believed to be caused by jinns within the community under review (Interview, Inusah 2018). This is not to conclude that the idea of jinns as the causative organisms of mental illness is an exclusive definition or interpretation of healers within the Aboabo community. Earlier cultures that adopted Muslim healing have featured jinns as important agents in discussions concerning diseases. Significantly, studies by Kpobi and Swartz (2018) and Ciftci et al. (2012) have also demonstrated and associated the cause of the ailment to evil spirits. This belief has risen out of the blend of Islam with ethnic sub-cultures of Ghana and the people of Aboabo in particular, which embraces the role of malevolent spirits in the discourse of health and healing. Aside evil spirits or jinn $(s)$, mental illness can be termed as a test or punishment from Allah who wills and causes everything to happen (Ciftci et al. 2012). In that case, the patient receives healing through Imams -who pose or act as intermediaries and Allah's agents on Earth. This notwithstanding, it was indicated that: "not all the mentally-ill can be healed" (Interview, Inusah 2018).

\footnotetext{
${ }^{8}$ Interview with Aboagye Francis and Ahmed Inusah, Spiritual center. 1 February 2018
} 


\section{Why rely on indigenous Muslim medical practices?}

Even in the contemporary age of avowed scientific healing, most people within the African region still patronize indigenous medical practices (Abdullahi 2011). Despite the attempts by colonial and some post-colonial governments to render the indigenous medical practices unpopular, majority of the population still derive their health needs from same medical practice. A recent study has revealed that $80 \%$ of Ghanaians use their indigenous medical practices to meet their primary healthcare needs (Krah et al. 2018). The literature has provided vast data on the factors that shape this tendency ranging from cost to trust among a myriad of others (Abdullahi 2011). Based on factors such as individual preference and economic motivations, the people of Aboabo continue to resort to the indigenous medical practices and Muslim healing practices in particular.

As already reported in the literature, the reliance on indigenous medical practices is relatively cheaper compared to orthodox medicine (Twumasi 1975; Abdullahi 2011; Adu-Gyamfi and Adjei 2017). In Aboabo, the general poverty rate of the people within the community is very glare. Our observation on the field was in consonance with the responses of our participants. We, observed (and confirmed from the participants), that the high rate of poverty among the people stimulates their reliance on the indigenous medical practices. They hinted that, Muslim traditional treatment or healing is relatively cheaper. In an interview with Makin, he hinted:

I charge for my service because I have to also provide for myself and my family. This notwithstanding, my charges are relatively cheaper compared to the charge (fee) of most of the scientific medical institutions. Kankrafu for instance may require a huge sum of money for surgical operation but I can heal my client of same disease and charge only 200 cedis. ...Although I believe the amount I receive from my clients is less for the services I discharge, I am not bothered; I believe I am serving humanity so Allah will reward me some day (Interview Makin, Aboabo 2018).

In an interview with a Muslim bone-setter, he also remarked that:

I do not charge a lot; my charges are dependent on the injury. A person with dislocation will have to provide seven cowries and two towels in addition to a lesser amount. For the treatment of serious fractures, I collect a white fowl, five towels, two new cloths and a cash payment (Interview Ibrahim, Aboabo 2018). 
The discussion above is in line with previous studies. Twumasi's (1975) study claims that indigenous healers during the pre-colonial era, did not charge their clients for their services, but relied on appreciation shown by the latter as their reward. Similarly, a current study by Adu-Gyamfi and Adjei reports same. In their study, they argue, among other things, that, while some indigenous healers charge their clients less, others still rely on the pre-colonial tendency as reported by Twumasi. This notwithstanding, the post-colonial indigenous healers do not deny their clients services for lack of resources (Adu-Gyamfi and Adjei 2017). However, in Aboabo, healers charge their clients but in relatively cheaper terms. Economic pressures and the nature of the ailments treated in the community can be reference points for the contrasts above. In an earlier study by Tabi et al. (2006), they have argued that indigenous healers living and working in the community have made their services available and affordable to the populations in Africa. This notwithstanding, from the current study, people who can afford hospital fees also patronize Muslim healing based on the perceived efficacy of the healers' practices. This stems from the indigenous healers' ability to treat spiritual ailments and irrational and unfamiliar diseases within the constructs of science (Tabi et al. 2006).

In Aboabo, we inferred from the responses of our respondents that Muslim healing practices have also been associated with fee for service. This notwithstanding, the charges have been lesser than that charged by orthodox practitioners. The result above re-echoes an earlier claim made by Owusu-Ansah (1983). Drawing nuggets from his study, he argues that some companions of Mohammed once treated a person bitten by snake and reported the incident to Mohammed, where the latter demanded his share of the reward (Owusu-Ansah 1983). Based on this, we argue that, accepting fees or charges for curing and healing purposes is a valid action in indigenous Muslim healing and medicine in particular. That notwithstanding, the collection of items such as fowls, cowries and towels have no Quranic basis nor is it featured in the cultures of Islam. To that extent, the collection of these items are indigenized forms of Muslim healing that tries to incorporate ideas that are common to one's cultural constructs.

\section{Trust}

In Africa, traditional healers have been significant resources commanding high respect in the local community (Hoff 1992; Liverpool et al. 2004). This has bred a sense of trust in the healers. Similarly, from this current study we inferred that most clients 
revolve around a built-trust as a patronization mechanism of Muslim indigenous medical practices within the Aboabo community. People within every neighborhood and Africa in particular dwell on a culture based on tradition rather than superimposed scientific knowledge (Liverpool et al. 2004), they tend to value the trust in their traditions which have subsisted for generations, including the indigenous medical practices and practitioners in particular. As healing practices have been channeled through various epochs, the healers and practitioners have developed longstanding trust from their clients. An interviewee hinted that:

Since I was born, I have known various medical practices including the one we receive from Makin and those from the 'developed hospitals'. Significantly, all my family members and I have relied on herbs (for normal diseases) and spiritual healing from Mallams within this community. I had been visiting one prominent Mallam till he died. Afterwards, Makin has been my physical and spiritual healer. I do not think I would visit the orthodox hospital once I receive all my health-related needs here (Mumuni, interview, Aboabo Number one, 2018).

The tendency of relying on one's longstanding traditions, especially in the area of medicine has the proclivity to result in self-medication. In the extract above, it has been clearly shown that aside relying on Muslim healers for the spiritual aspect of health care; Mumuni relies on trust in his tradition to self-administer herbs to treat what he terms as "normal diseases." Similarly, it has been reported elsewhere that trust in traditional medical systems and spiritual healing in Africa and Ghana in particular, deter patients from accessing the hospitals unless symptoms of a particular ailment become intensive and unbearable (Amoah et al. 2014). This could be a conundrum to the traditional and orthodox medical systems and healthcare in particular.

In Aboabo, the clients interviewed revealed that Muslim healers succeed in restoring the health of many, if not all their clients. In support, Aboagye's father, a pastor, opined that there has been testimonies about the efficacy of the practices and utilization of Muslim healing from friends and neighbours who had initially benefited from their visit and this pushed them to give it a try. Significantly, traditional healers have been available and accessible to the local people. These healers and their services are advertised through the testimonies from their clients to others in the community and beyond (Adu-Gyamfi 2015; Twumasi 1975; Hoff 1992). As already provided in the exegesis above, clients' testimonies further intensify the built-trust in the healers. Also, based on the testimonies, most of the clients believed that there is a high level of 
Muslim medical patronage in Aboabo due to the healers' proclivity to cure spiritual ailments. It is believed by the various participants that diseases that are spiritual and are not meaningful within the praxes and exegesis of orthodox medicine and scientific hospitals in particular, push more people toward Muslim healing as either the last resort or a supplement to scientific medicine.

\section{The challenge of using indigenous medical practices in Aboabo}

The use of indigenous medical systems and indigenous Muslim healing traditions in Aboabo in particular has not existed without challenges. We observed during our study that almost all the practitioners interviewed had the challenge of extracting medical substances from plant materials. The mode of preparing herbal medicine appears very crude and labor intensive. In their recent study, Krah et al. (2018) argue that traditional healers lack equipment needed for the successful discharge of their roles within the community. Similarly, in Aboabo, the preparation of herbal medicine, according to Makin, is always delayed. More so, in Aboabo, we observed improper handling of the plants as well as unwanted particles and impurities which were regularly mixed with the extracts. This has the potency of intensifying a patient's poor health or medical condition.

In an interview with the practitioners, they hinted that locating medicinal plants are now problematic. Practitioners and especially herbal practitioners in Aboabo find it challenging to collect roots, leaves or plants used in the preparation of concoctions and decoctions. Significantly, human activities and the advancement of towns have rendered medicinal plants exiguous. This is in accordance with the work of Krah and her contemporaries who put forward the argument that healers now have to travel to places within the forests and further into the bushes for some plants materials needed to prepare herbal medicines (Krah et al. 2018). In Aboabo however, a new perspective was found. Makin opined that, the lack of medicinal plants within the Aboabo community forces them to sometime purchase some materials needed to prepare concoctions from their fellow healers and practitioners. To that extent, there seems to be some level of cooperation among the various healers within the community.

Aside from facing a challenge in the preparation of potions, the storage facilities available for almost all the healers interviewed appeared problematic. Within the literature, authors have supported the argument that inadequate storage facilities is derailing the course of traditional medical practices (Thillaivanan and Samraj 2014; 
Krah et al. 2018). As argued by Krah et al. (2018), healers in Aboabo also have limited bottles to keep their concoctions and decoctions. On the field, we observed a massive surge in the use of plastic containers ${ }^{9}$ as the main containers for storage and distribution of medical potions (see Fig. 2). In an interview with Ibrahim, he hinted that:

I am faced with limited finance. You know we charge our clients less thereby limiting our savings and financial standing. Money needed to even purchase plastic bottles is a problem. I have to rely on those water bottles, which are washed after collection to prepare and keep my herbal concoctions. In that case, I do not prepare much, for fear of the concoction going bad (Interview Ibrahim, Aboabo Number one, 2018).

Also, there is the absence of mediums like refrigerators to ensure freshness of medical concoctions.
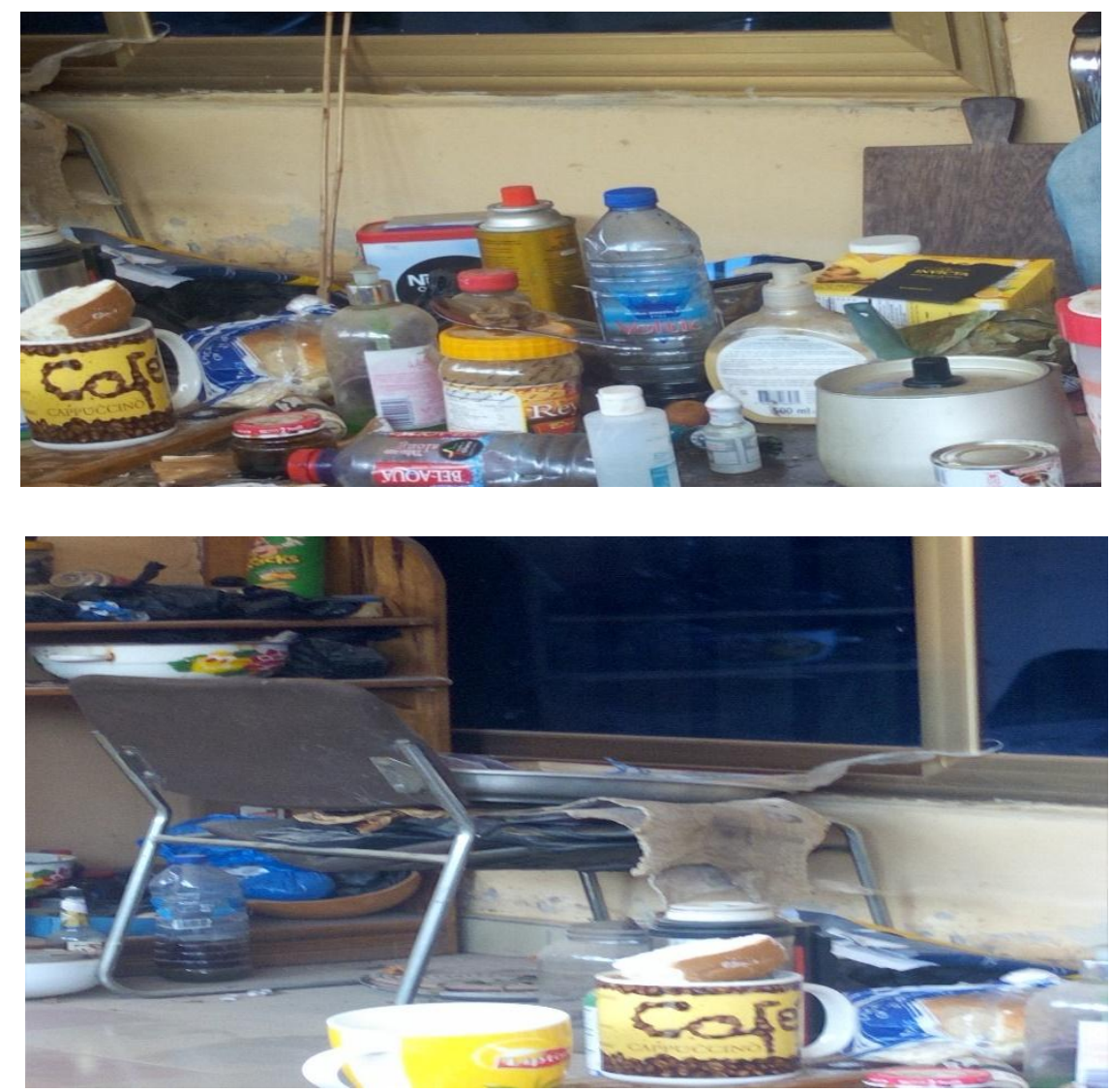

Fig. 2 Images taken from various Muslim healing centers showing materials that are used in the process of healing. The white plastic bottle with blue cover is used as a container to house the prepared concoctions and decoctions.

Concerning spiritual healing, the term has been defined by Adu-Gyamfi (2016) as any practice that makes no meaning within the realm of science. This healing is

\footnotetext{
${ }^{9}$ This is normally a used water container that has been disposed by plastic water consumers
} 
believed to emanate from the African belief in the social or supernatural causation model which regards evil spirits as disease causation organisms (Twumasi 1975; AduGyamfi 2016). It can be argued that spiritual healing has been diffused across the borders of Africa.

Our field research revealed that, while the efficacy and credibility of this form of healing pose a concern to others, the patients who benefit from spiritual healing are usually not worried about its nature; they focus on the outcome. The major problem of Muslim spiritual healing in Aboabo simulates information from earlier findings. Significantly, healing by incantations and spells and other irrational means challenges orthodox scientific notions and methods of prognosis and diagnosis (Adu-Gyamfi 2016). For instance, it will be difficult for scientists to pin point what is in a particular talisman or amulet for treatment. Also, basing on the recitation of the Holy Quran over a sick person to be cured becomes a difficult tendency to be accepted within science and technology. In our study we argue that the Rukya or Quran verses written and washed off the slates for cure has the proclivity of contaminating the potion itself aside its chemical properties known to combat diseases caused by germs. Within the literature, concerns have been raised by authors concerning the issue of cleanliness of indigenous medical practices. The works of Abdullahi (2011), Thillaivanan and Samraj (2014) and Krah et al. (2018) have demonstrated that the above concern is affecting the integration of the two main medical systems in Ghana and elsewhere.

The government of Ghana through the auspices of the Ministry of Health has formed a sub-group called the Traditional Medicine Practice Council (TMPC), whose responsibility is to ensure the delivery of proper traditional medical services (TMPC 2018). Also, the group above is tasked with checking quackery practices among indigenous health workers (TMPC 2018). In doing this, they issue certificates to deserved indigenous healers. Owing to this, healing and healers in the Aboabo community have been affected both on the positive and negative notes. Data collected from the field indicated that while the quest for acknowledgment among indigenous healers leads them to modernize their practices by ensuring hygienic protocols and also obtaining certificates, most of the powerful healers who find it difficult to obtain certificates have ceased to practice indigenous medical practices in the Aboabo community. That notwithstanding, these healers who have been sidelined still influence 
the healing practices of the community by teaching the other certified healers the nittygritties of the art of indigenous Muslim healing among other things.

\section{Conclusion}

Over the course of time, many societies that have accepted Islam have blended what was already present in their native culture with what was, rightly and wrongly, linked to Islam. Here, we have presented an example of this combination related to the issue of healing processes of traditional healers in a sub-Saharan African community "Aboabo".

Based on information gathered from interviews and observations, the current study has discussed and analyzed indigenous Muslim healing in Aboabo and how it shapes the discussions on health within same community. It has paid attention to how Muslim communities have been adopted and indigenized to fit local health needs. As a community with majority of its indigenes as Muslims, people have relied on Muslim healing practices in the community for their healthcare needs over time. Notwithstanding the scientific medical practices being recognized widely in Ghana, a significant number of the populace still within the Aboabo community derive their health needs from this form of healing due to reasons spanning cost, trust and availability. From the current study, we deduced that there are different views and approaches to Muslim healing. Among other things, healers in the community treat physical, psychological and spiritual ailments. We have paid particular attention to the mode of treating ailments with both medications and legitimate prayers and incantations by indigenous Muslim healers.

Despite their contribution to healthcare delivery, the healers of the Aboabo community have not discharged their duties without significant challenges. Lack of support, equipment, storage facilities, finance and concerns on the contamination of potions and lack of proper hygiene are among the various detriments to their practices. These challenges in addition to those that have already been discussed in the literature have posed questions on the efficacy of indigenous medical practices and Muslim healing and Muslim traditional healing in particular. That notwithstanding, participants and members of the community at large have testified about the perceived efficacy of Muslim healing practices coupled with less charges in the community. This serves as a premise upon which the government should be called upon to extend resources towards the development of strategies that can support and further regulate the activities of these 
practitioners. The reason is obvious, when the government and related agencies do not get involve; the harmful aspects of the practice and the activities of practitioners can hurt the social and psychological well-being of the individuals who patronize same.

From the current study, we have raised questions and highlighted key issues for policy makers and stakeholders in the Aboabo community and Ghana in general, which has wider ramifications on the African continent and West-Africa in particular. Essentially, it is necessary for the process of collecting and preparing herbal medicines to be documented by both secular and Muslim authors to aid researchers to ascertain the nature of healing activities and processes within Muslim communities. This has the proclivity to aid Muslim healing and spiritual healing in particular to be studied as scholarship within institutions as witnessed in Pakistan, Tanzania and other countries. It is imperative to also state that there is the need for the crude methods used in the preparation and preservation of herbal medicines to be reformed. In addition, herbal and botanic gardens should be available for healers to easily access plants of their choice. On the part of government, there is the need to financially support traditional healers through the provision of logistics needed for medical preparation. The Ministry of Health in Ghana should enhance the sponsorship of legislative instruments to check, regulate and enhance traditional medical practices in Ghana.

Conflicts of Interest: authors declare no conflict of interest

\section{References}

Abdullahi A.A. 2011. "Trends and challenges of traditional medicine in Africa" African Journal of Traditional, Complementary and Alternative Medicines, 8(5S): 115- 123. DOI: $10.4314 /$ ajtcam.v8i5S.5

Adu-Gyamfi S. 2014. "Islamic Healing among the People of Sampa in Ghana: An Empirical Study." International Journal of Arts and Humanities, 3(7): 105-114.

Adu-Gyamfi S. 2016. "Spiritual and Indigenous Healing Practices among the Asante People of Ghana: a Testimonial from the Twenty-First Century Practitioners and Recipient in Kumasi." Journal of Basic and Applied Research International, 12 (1): 3950 .

Adu-Gyamfi S. and Adjei R. 2017. Traditional Medicine: Narratives from an Indigenous People. Beau Bassin: Lambert Academic Publishing.

Akyeampong E. 2006. Northern Factors in Asante History. Diversity and tolerance in the Islam of West Africa. Available at: http://aodl.org/islamictolerance/asantehistory/ 
Ali S.A., Parveen N., Ali A.S. 2018. "Links between the Prophet Muhammad (PBUH) recommended foods and disease management: A review in the light of modern superfoods." International journal of health sciences, 12(2): 61-69.

Amoah S. K. S. 2014. "Herbalists, Traditional Healers and Pharmacists: AView of the Tuberculosis in Ghana." Brazilian Journal of Pharmacognosy, 24: 89-95.

Barnard A. 2000. "Diffusionist and Culture-Area Theories. In History and Theory in Anthropology. Cambridge: Cambridge University Press. Pp. 47-60.

DOI: $10.1017 / \mathrm{CBO} 9780511808111.005$

Carter Y. J. 2018. "Path(s) of Remembrance: Memory, Pilgrimage, and Transmission in a Transatlantic Sufi Community". A dissertation submitted in partial satisfaction of the requirements for the degree of Doctor of Philosophy in Anthropology in the Graduate Division of the University of California, Berkeley.

Chaabani H. 2011. Compatibility of the holy Qurean with sciences: anthropological concepts as an example. International Journal of Modern Anthropology. 1(4): 78 - 84. DOI: http://dx.doi.org/10.4314/ijma.v1i4.5

Chaabani H. 2019. The miraculous dynamism of the Qurean: An example of a modern reading reveals a DNA designation. International Journal of Modern Anthropology. 2 (12): 15 - 61. DOI: http://dx.doi.org/10.4314/ijma.v2i12.1

Ciftci A., Jones N. and Corrigan P W. 2012. "Mental Health Stigma in the Muslim Community." Journal of Muslim Mental Health, 7(1): n.d.

DOI: http://dx.doi.org/10.3998/jmmh.10381607.0007.102

Colpe C. 1977. "Syncretism and Secularization: Complementary and Antithetical Trends in New Religious Movements? History of Religion, 17(2): 158 - 176

Diah N.M., Hossain DN., Mustari S., Ramli N.S. 2014. "An Overview of Anthropological Theories." International Journal of Humanities and Social Science, 4(10): 155-164.

Droogers A. 1989. "Syncretism: The Problem of Definition, the Definition of the Problem." In Gort JD. (ed). et al. Dialogues and Syncretism: An Interdisciplinary Approach. Amsterdam: William B. Eerdmans Publishing Company. Pp. 7-25

Edwards R. 2011. "Herbs and Healers of the North: Medicine, Practices and Philosophies in Islamic and Traditional Healing in Northern Ghana." Independent Study Project (ISP) Collection, 1250. https://digitalcollections.sit.edu/isp collection/1250

Farooqi Y. N. 2006. "Traditional Healing Practices Sought by Muslim Psychiatric Patients in Lahore, Pakistan." International Journal of Disability, Development and Education, 53:4, 401-415.

DOI: $10.1080 / 10349120601008530$

Hein A. 2014. "Introduction: Diffusionism, Migration, and the Archaeology of the Chinese Border Regions." In Hein A. (ed.) The 'Crescent-Shaped CulturalCommunication Belt': Tong Enzheng's Model in Retrospect. Oxford: British Archaeological Reports. Pp. 1-17. 
Hoff W. 1992. "Traditional Healers and Community Health." World Health Forum, Vol. 13.

Interview with Abass Halima, work place, Aboabo bus stop, 9 February 2018.

Interview with Aboagye Francis, Ahmed Inusah spiritual center, Aboabo, No 2, 1 February 2018

Interview with Aliu Atapasa Mallam, residence, Aboabo No 1, 6 February, 2018.

Interview with Baba Jibo, work place, Dagomba line No 2, 2 February 2018.

Interview with Inusah Ahmed, residence, Aboabo No 1, 7 February 2018.

Interview with Makin Shehu, Residence, Aboabo No 2, 29 January 2018.

Interview with Na Lado, Ibrahim, residence, Aboabo No 2, 3 February 2018.

Interview with Owusu Kwame, Na Laado spiritual Centre, Aboabo No 2, 9 February 2018

Khalifa N. and Hardie T. 2005. "Possession and jinn." Journal of the Royal Society of Medicine, 98: 351-353.

Kpobi L.N.A. and Swartz L. 2019. "Muslim Traditional Healers in Accra, Ghana: Beliefs About and Treatment of Mental Disorders." Journal of Religion and Health, 58: 833-846

Krah E., de Kruijf J., Ragno L. 2018. "Integrating Traditional Healers into the Health Care System: Challenges and Opportunities in Rural Northern Ghana." J. Community Health, 43, 157-163. DOI: https://doi.org/10.1007/s10900-017-0398-4

Lim A., Hoek HW., Blom J.D. 2015. "The attribution of psychotic symptoms to jinn in Islamic patients." Transcultural Psychiatry, 52(1): 18-32. DOI: $10.1177 / 1363461514543146$ tps.sagepub.com

Liverpool J., Randell A., Melba J., Ebba K.E., Shelly F. et al. 2004. "Western Medicine and Traditional Healers: Partners in the Fight against HIV/AIDs." Journal of the National Medical Association, Vol. 96 (6): 822-825.

Mensah C.A. 2010. Causes and Consequences of Informal Settlement Planning in Ghana: A Case Study of Aboabo, a Suburb of Kumasi Metropolis. A Thesis Submitted to the Department of Geography and Regional Planning of the Faculty of Social Sciences, University of Cape Coast in Partial Fulfilment of the Requirements for Award of Master of Philosophy Degree in Geography.

Owusu-Ansah D. 1983. "Islamic Influence in a Forest Kingdom: The Role of Protective Amulets in Early $19^{\text {th }}$ Century Asante”.Trans-African Journal of History, vol. 12: 100133.

Sackey B.M. 2002. "Women, Religion and Health: Faith Healing in Accra, A Preliminary Study of Rev. Christie Doh-Tetteh's Solid Rock Chapel International. Occasional Research Papers, Series 2000, Paper 5. 
Seebaway Z. 2011. Muslim healing: Theory and Practice. Saarbrucken: LAP LAMBERT Academic GmbH \& Co.KG.

Stewart C. 1999. "Syncretism and Its Synonym: Reflections on Cultural Mixture." Diacritics, 29(3): 40-62.

Tabataba'i H. 1984. "Tafsir al-Mizan (Persian), Qum.” Intesharat-e Islami, 20 (1363): n.d. (in Cd Rom Jame).

Tabi M.M., Powell M. \& Hodnicki D. 2006. "Use of traditional healers and modern medicine in Ghana." International Nursing Review, 53: 52-58.

Thillaivanan S. and Samraj K. 2014. "Challenges, constraints and opportunities in herbal medicines-a review." International journal of Herbal medicine, 2(1): 21-24.

Traditional Medicine Practice Council. 2018. "Integration of Herbal Medicine in Ghana's Healthcare Program.” Available online at:

https://tmpcghana.org/2018/02/05/integration-of-herbal-medicine-in-ghanas-healthcareprogram/

Twumasi P. A. 1975. Medical Systems in Ghana: A Study of Medical Sociology. Accra: Ghana Publishing Corporation.

White J.W. 1979. Composition of honey. In Honey: A Comprehensive Survey. London Heinemann: Heinemann.

Yusif M. 2014. "Islamic and Human Right: A Case Study of Hohoe Muslim community”. Master's Thesis: Dept. of Rel. Stu, KNUST.

To cite this article:

Adu-Gyamfi S., Teikillah A., Yakubu Nyaaba A., Marciana Kuusaana M., Dompreh Darkwa B., Tomdi L. 2020. Muslim Healers and Healing: An Ethnographic Study of Aboabo Community of Ghana. International Journal of Modern Anthropology. 2 (14): 291- 316 DOI: http://dx.doi.org/10.4314/ijma.v2i14.4

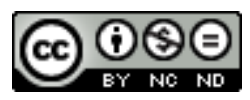

This article, as all articles published in this journal, is under The Creative Commons Attribution:

Attribution-NonCommercial-NoDerivatives 4.0 International (CC BY-NC-ND 4.0).

https://creativecommons.org/licenses/by-nc-nd/4.0/ 